\title{
PENGARUH PENGANGGURAN DAN INFLASI TERHADAP PERTUMBUHAN EKONOMI DI SUMATERA UTARA
}

\author{
Umi Kalsum \\ Dosen Fakultas Ekonomi dan Bisnis Universitas Muhammadiyah Sumatera Utara \\ Email : kalsum.umi16@yahoo.com
}

\begin{abstract}
ABSTRAK
Makro ekonomi adalah studi tentang kegiatan ekonomi di suatu negara. Indikator ekonomi makro adalah inflasi, pengangguran, dan pertumbuhan ekonomi. Tujuan dari penelitian ini adalah untuk melihat pengaruh antara pengangguran dan inflasi terhadap pertumbuhan ekonomi di Sumatera Utara. Penelitian ini menggunakan metode regresi berganda yang datanya diambil dari tahun 2011- 2015 per semester. Akhirnya penelitian ini hanya menunjukkan variabel pengangguran yang berpengaruh signifikan terhadap pertumbuhan ekonomi, sedangkan inflasi tidak berpengaruh signifikan terhadap pertumbuhan ekonomi.
\end{abstract}

Kata kunci: inflasi, pengangguran, pertumbuhan ekonomi.

\section{PENDAHULUAN}

Pembangunan ekonomi pada hakekatnya adalah serangkaian usaha kebijaksanaan yang bertujuan untuk meningkatkan taraf hidup masyarakat, memperluas kesempatan kerja dan mengarahkan pembagian pendapatan secara merata. Masalah kesempatan kerja atau pengangguran merupakan masalah yang sangat sulit dihindari oleh suatu negara atau daerah dan dapat menimbulkan masalah sosial seperti tindakan kriminalitas dan masalah ekonomi. Kondisi tersebut dapat menurunkan tingkat kesejahteraan dan daya beli masyarakat. Semakin rendah angka pengangguran maka semakin makmur kehidupan masyarakat suatu negara, begitu pula sebaliknya.

Suatu negara dipandang berhasil atau tidak dalam memecahkan permasalahan ekonomi negaranya sendiri dapat dilihat dari ekonomi makro dan mikro negara tersebut. Ekonomi makro adalah kajian tentang aktivitas yang membahas ekonomi suatu Negara. Salah satu indikator ekonomi makro yang digunakan untuk melihat/mengukur stabilitas perekonomian suatu negara adalah inflasi. Perubahan dalam indikator ini akan berdampak terhadap dinamika pertumbuhan ekonomi. Dalam perspektif ekonomi, inflasi merupakan fenomena moneter dalam suatu negara dimana naik turunnya inflasi cenderung mengakibatkan terjadinya gejolak ekonomi. Inflasi adalah suatu gejala di mana tingkat harga umum mengalami kenaikan secara terus menerus.

\section{LANDASAN TEORITIS Pertumbuhan Ekonomi}

Pertumbuhan ekonomi merupakan suatu tolak ukur untuk keberhasilan pembangunan di suatu Negara khususnya dibidang ekonomi. Pertumbuhan ekonomi dapat diukur dari tingkat pertumbuhan Produk Domestik Bruto (PDB) sedangkan untuk ruang lingkup nasional dan Produk Domestik Regional Bruto (PDRB) untuk lingkup wilayah. Selain dipengaruhi faktor internal, pertumbuhan ekonomi di suatu Negara dapat juga dipengaruhi oleh faktor eksternal, terutama setelah era ekonomi yang semakin mengglobal. Secara internal ada tiga komponen utama yang menentukan pertumbuhan ekonomi tersebut adalah pemerintah, dunia usaha, dan masyarakat. 
Menurut Murni (2006: 173), pertumbuhan ekonomi adalah suatu kondisi yang terjadi adanya perkembangan GNP potensial yang mencerminkan adanya pertumbuhan output perkapita dan meningkatnya standar hidup di masyarakat. Menurut Sukirno (2010) Teori Schumpeter menekankan tentang pentingnya peranan pengusaha di dalam mewujudkan pertumbuhan ekonomi. Schumpeter menyatakan makin tinggi tingkat kemajuan suatu ekonomi semakin terbatas kemungkinan untuk mengadakan inovasi yang baru.

\section{Pengangguran}

Menurut Suparmoko (2007) pengangguran adalah ketidak mampuan angkatan kerja untuk memperoleh pekerjaan sesuai dengan yang mereka butuhkan atau mereka inginkan. Jadi dapat disimpulkan pengangguran adalah suatu kondisi di mana seseorang yang sudah tergolong angkatan kerja belum mendapat pekerjaan dan berusaha mencari pekerjaan. Sedangkan menurut Badan Pusat Statisitk (BPS) dalam indikator ketenagakerjaan, pengangguran merupakan penduduk yang tidak bekerja tetapi sedang mencari pekerjaan atau sedang mempersiapkan suatu usaha baru atau penduduk yang tidak mencari pekerjaan karena sudah diterima bekerja tetapi belum mulai bekerja. Menurut Murni (2006) pengangguran adalah orang yang tidak mempunyai pekerjaan atau tidak mempunyai penghasilan. Sukirno (2008) menjelaskan pengangguran adalah suatu keadaan di mana seseorang tergolong dalam angkatan kerja ingin mendapatkan pekerjaan tapi belum dapat memperolehnya.

\section{Inflasi}

Menurut Sukirno (2006) Inflasi tarikan permintaan, yaitu Inflasi ini biasanya terjadi pada masa perekonomian berkembang dengan pesat. Kesempatan kerja yang tinggi menciptakan tingkat pendapatan yang tinggi dan selanjutnya menimbulkan pengeluaran yang melebihi kemampuan ekonomi mengeluarkan barang dan jasa. Sedangkan Inflasi desakan biaya, yaitu Inflasi yang berlaku pada masa perekonomian berkembang dengan pesat dan tingkat pengangguran sangat rendah. Apabila perusahaan-perusahaan masih menghadapi permintaan yang bertambah, mereka akan berusaha menaikkan produksi dengan cara memberikan gaji dan upah yang lebih tinggi kepada pekerjanya. Langkah ini membuat biaya produksi meningkat, yang akhirnya menyebabkan kanaikan harga berbagai barang. Suseno dan Astiyah (2009) mengartikan inflasi sebagai suatu kecenderungan meningkatnya harga-harga barang dan jasa secara umum dan terus menerus.

Menurut Budiono (2008) inflasi adalah proses kenaikan harga-harga umum barangbarang secara terus menerus. Sedangkan Sukirno (2008) mendefinisikan inflasi sebagai proses kenaikan harga-harga yang berlaku dalam suatu perekonomian. Berdasarkan definisi mengenai inflasi di atas maka dapat disimpulkan bahwa inflasi merupakan kecenderungan naiknya harga barang secara umum dan terjadi secara terusmenerus.

\section{Kerangka Konseptual}

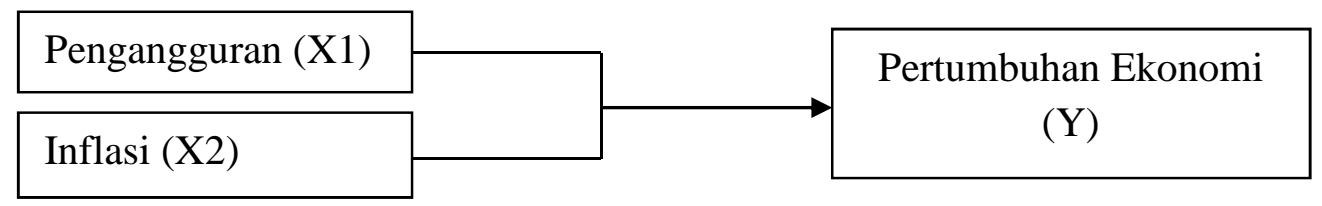

Gambar 1. Kerangka Konseptual 


\section{METODE PENELITIAN}

Dalam melakukan penelitian ini, agar tidak menyimpang dari permasalahan maka penulis dengan pembahasan pengaruh pengangguran dan inflasi terhadap pertumbuhan ekonomi pada priode tahun 2011 - 2015 yang bertujuan untuk mengetahui pengaruh antara variabel satu dengan variabel yang lainnya.

\section{Defenisi Operasional Variabel \\ Variabel Dependen}

Variabel dependen (Y) dalam penelitian ini adalah pertumbuhan ekonomi. Pertumbuhan ekonomi merupakan kenaikan Produk Domestik Bruto/ Pendapatan Nasional Bruto tanpa memandang apakah kenaikan tersebut lebih besar atau lebih kecil dari tingkat pertumbuhan penduduk atau apakah perubahan struktur ekonomi terjadi atau tidak. Data operasional yang digunakan dalam penelitian ini diperoleh dari Badan Pusat Statistik (BPS) yaitu berdasarkan perhitungan per semester tahun 2011-2015 yang dinyatakan dalam bentuk persentase.

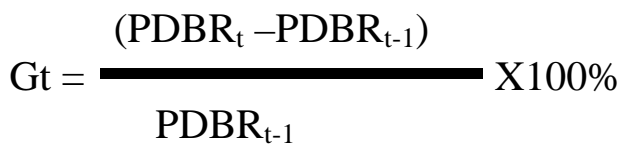

\section{Variabel Independen \\ Pengangguran}

Pengangguran yaitu suatu ukuran yang dilakukan jika seseorang tidak memiliki pekerjaan tetapi mereka sedang melakukan usaha secara aktif dalam empat minggu terakhir untuk mencari pekerjaan.

$$
\text { Tingkat pengangguran }=\frac{\text { Jumlah Pengangguran }}{\text { Jumlah angkatan kerja }} \times 100 \%
$$

\section{Inflasi}

Inflasi adalah suatu gejala di mana tingkat harga secara umum mengalami kenaikan secara terus menerus dalam penelitian ini data diperoleh melalui Bank Indonesia (BI) yaitu berdasarkan perhitungan per semester tahun 2011-2015 yang dinyatakan dalam bentuk persentase.

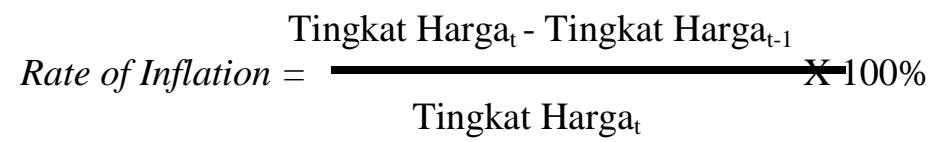

\section{HASIL DAN PEMBAHASAN}

Hasil Analisis Data

Analisis regresi linier berganda dalam penelitian digunakan untuk mengetahui pengaruh pengangguran (X1) dan Inflasi (X2) terhadap pertumbuhan ekonomi (Y).

\section{Uji Asumsi Klasik}

Sebelum dilakukan pengujian hipotesis, terlebih dahulu dilakukan pengujian mengenai ada tidaknya pengaruh pengangguran dan inflasi terhadap pertumbuhan ekonomi. Uji ini meliputi : uji normalitas, uji multikolinearitas, uji autokorelasi dan uji heteroskedastisitas.

1. Uji Normalitas 
Salah satu cara untuk melihat apakah dalam model penelitian berdistribusi normal atau tidak dapat dideteksi melalui analisis statistik (uji one sample kolmogrov test).

Tabel 1

One-Sample Kolmogorov-Smirnov Test

\begin{tabular}{|ll|r|}
\hline & & $\begin{array}{r}\text { Unstandardized } \\
\text { Residual }\end{array}$ \\
\hline Normal Parameters ${ }^{\mathrm{a}}$ & Mean & 165 \\
& Std. & .0000000 \\
& Deviation & 1.65764809 \\
Most Extreme & Absolute & .079 \\
Differences & Positive & .069 \\
Kolmogorov-Smirnov Z & Negative & -.079 \\
Asymp. Sig. (2-tailed) & & 1.021 \\
\hline a. Test distribution is Normal. & .248 \\
\hline
\end{tabular}

Hasil pengujian ini menunjukkan bahwa semua variabel mempunyai hubungan terhdap pertumbuhan ekonomi. Hal ini dapat dilihat dari nilai sig (2-tailed) sebesar $0.248>\alpha=0.05$ berarti dapat dijelaskan bahwa data berdistribusi normal.

2. Uji Multikolinearitas

Pengujian ini dilakukan untuk menguji apakah model regresi ini ditemukan ada tidaknya korelasi antara variabel independen dengan melihat nilai tolerance dan variance inflation factor (VIF).

Tabel 2

Coefficients $^{a}$

\begin{tabular}{|ll|r|r|}
\hline \multirow{2}{*}{ Model } & \multicolumn{2}{|c|}{ Collinearity Statistics } \\
\cline { 3 - 4 } & & \multicolumn{1}{|c|}{ Tolerance } & \multicolumn{1}{c|}{ VIF } \\
\hline 1 & Pengangguran & .994 & 1.006 \\
& Inflasi & .994 & 1.006 \\
\hline
\end{tabular}

a. Dependent Variable: Pertumbuhan

Dari hasil uji regresi diatas maka dapat di simpulkan bahwa variabel independen tidak terjadi multikolinearitasdikarena hasil; nilai tolerance $>0.1$ dan nilai $\mathrm{VIF}<10$.

3. Uji Heterokedastisitas

Tabel 3

Coefficients $^{\text {a }}$

\begin{tabular}{|c|c|c|c|c|c|}
\hline \multirow[b]{2}{*}{ Model } & \multicolumn{2}{|c|}{$\begin{array}{l}\text { Unstandardized } \\
\text { Coefficients }\end{array}$} & $\begin{array}{c}\text { Standardized } \\
\text { Coefficients }\end{array}$ & \multirow[b]{2}{*}{$t$} & \multirow[b]{2}{*}{ Sig. } \\
\hline & B & Std. Error & Beta & & \\
\hline 1 (Constant) & 4.616 & .163 & & 28.250 & 0 \\
\hline Pengangguran & -.146 & .056 & -.200 & -2.593 & 0 \\
\hline Inflasi & .000 & .001 & -.037 & -.480 & \\
\hline
\end{tabular}

a. Dependent Variable: Pertumbuhan 
Berdasarkan pada tabel diatas dapat dilihat pada kolom nilai signya lebih besar dari 0.05 sehingga dapat disimpulkan bahwa tidak terjadi heterokedastisitas.

4. Uji Autokorelasi

Tabel 4

Model Summary

\begin{tabular}{l|c|r|c|c|r|}
\hline Model & $\mathrm{R}$ & $\mathrm{R}$ Square & $\begin{array}{c}\text { Adjusted R } \\
\text { Square }\end{array}$ & $\begin{array}{c}\text { Std. Error } \\
\text { of the } \\
\text { Estimate }\end{array}$ & $\begin{array}{c}\text { Durbin- } \\
\text { Watson }\end{array}$ \\
\hline 1 & $.201^{\mathrm{a}}$ & .040 & .028 & 1.66785 & 1.168 \\
\hline
\end{tabular}

Pada tabel diatas dapat dilihat hasil uji durbin- Watson yang menunjukkan nilai 1.168 sedang dalam tabel DW untuk $\mathrm{K}=3$ dan $\mathrm{N}=165$, besarnya DW- tabel yaitu dl (batas luar $0=0,664$, nilai 4-dl $=3.336$. maka dapat disimpulkan du $0.664<\mathrm{DW}=$ $1.168<4-\mathrm{du}=3.336$ yang berarti tidak adanya autokorelasi dalam model persamaan regresi ini.

\section{Pengujian Hipotesis}

Pengaruh pengangguran dan inflasi terhadap pertumbuhan ekonomi di Sumatera Utara pada priode 2011-2015 dapat dilihat dari analisis regresi berganda. Di dalam penelitian ini uji hipotesis menggunakan uji simultan dan uji parsial.

1. Pengujian secara simultan (uji F)

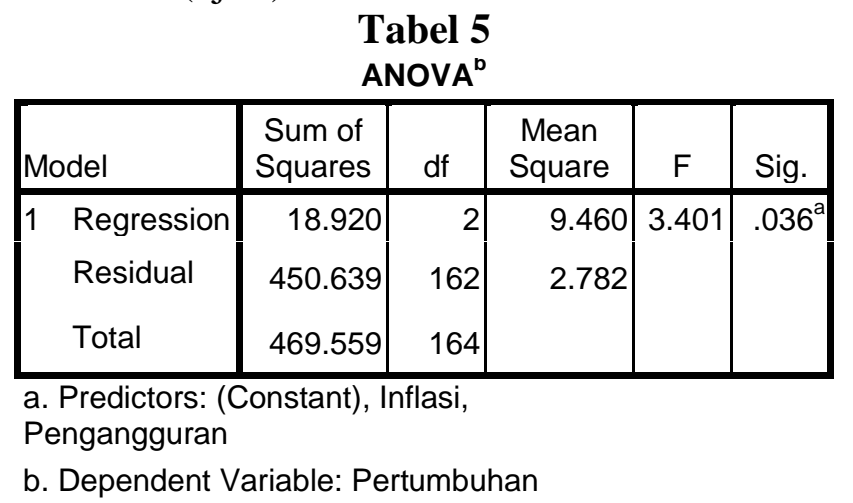

Pada tabel diatas dapat dilihat nilai F signifikan sebesar 0.036 dan $\mathrm{F}$ hitung sebesar 3.401. nilai $F$ tabel berdasarkan tabel statistik sebesar 2.89. dengan demekian dapat disimpulkan F signifikan $0.036<\alpha=0.05$ dan $F$ hitung : $3.401>\mathrm{f}_{\text {tabel }}: 2.89$ maka dapat disimpulkan bahwa secara simultan variabel pengangguran dan inflasi terhadap pertumbuhan ekonomi berpengaruh signifikan.

2. Pengujian secara Parsial (uji t)

Nilai konstan (a) mempunyai nilai konstan sebesar 4.616 yang artinya jika tidak ada pengaruh variabel pengangguran dan inflasi yang di anggap konstan maka variabel pertumbuhan ekonomi sebesar 4.616 di sumatera utara selama periode 20112015.

Nilai signifikan untuk variabel pengangguran sebesar 0.010 bahwa pengangguran dibawah dari 0.05 maka dapat disimpulkan bawa pengangguran berpengaruh signifikan terhadap pertumbuhan ekonomi. Selai itu nilai signifikan dapat kita lihat pada pengujian data diatas menunjukan nilai sebesar -2.593. maka 
dapat disimpulkan bahwa variabel pengangguran berpengaruh secara parsial terhadap pertumbuhan ekonomi.

Tabel 6

Coefficients $^{\mathrm{a}}$

\begin{tabular}{|c|c|c|c|c|c|}
\hline \multirow[b]{2}{*}{ Model } & \multicolumn{2}{|c|}{$\begin{array}{l}\text { Unstandardized } \\
\text { Coefficients }\end{array}$} & $\begin{array}{c}\text { Standardized } \\
\text { Coefficients }\end{array}$ & \multirow[b]{2}{*}{$\mathrm{T}$} & \multirow[b]{2}{*}{ Sig. } \\
\hline & B & Std. Error & Beta & & \\
\hline 1 (Constant) & 4.616 & .163 & & 28.250 & .000 \\
\hline Pengangguran & -.146 & .056 & -.200 & -2.593 & .010 \\
\hline Inflasi & .000 & .001 & -.037 & -.480 & .632 \\
\hline
\end{tabular}

a. Dependent Variable:

Pertumbuhan

Nilai signifikan untuk variabel inflasi 0.632 bahwa inflasi lebih besar dari 0.05 maka dapat di simpulkan bahwa inflasi tidak berpengaruh parsial terhadap pertumbuhan ekonomi.

\section{PEMBAHASAN}

Variabel pengangguran memiliki nilai signifikan sebesar 0.010 lebih kecil dari 0.05 maka dapat disimpulkan bahwa pengangguran berpengaruh signifikan terhadap pertumbuhan ekonomi. Hasil t-hitung pada tabel diatas menunjukkan -2,593 dengan ttabel sebesar 2,89. Artinya t-hitung lebih kecil dari t-tabel, sehingga dapat disimpulkan bahwa pengangguran berpengaruh signifikan terhadap pertumbuhan ekonomi. Penjelasan diatas membuktikan bahwa pengangguran menunjukkan penurunan terhadap pertumbuhan ekonomi setiap tahunnya.

Variabel inflasi memiliki nilai signifikan sebesar 0,632 lebih besar dari 0,05 maka dapat disimpulkan bahwa variabel inflasi tidak berpengaruh signifikan terhadap pertumbuhan ekonomiu. Hasil t-hitung menunjukkan nilainya sebesar -0,480 dan t-tabel sebesar 2,89. Artinya t-hitung lebih kecil dari t-tabel yang menunjukkan bahwa variabel inflasi tidak mempunyai pengaruh signifikan dengan pertumbuhan ekonomi. Penjelasan diatas membuktikan bahwa inflasi menunjukkan penurunan terhadap pertumbuhan ekonomi setiap tahunnya.

\section{KESIMPULAN}

Berdasarkan hasil analisis dan pengujian data yang dilakukan secara statistik maka diperoleh beberapa kesimpulan sebagai berikut :

1. Hasil penelitian menunjukkan bahwa variabel pengangguran berpengaruh signifikan terhadap pertumbuhan ekonomi di Sumatera Utara. Artinya ketika pengangguan meningkat maka pertumbuhan ekonomi meningkat

2. Hasil penelitian selanjutnya menunjukkan bahwa variabel inflasi tidak berpengaruh signifikan terhadap pertumbuhan ekonomi di Sumatera Utara. Artinya ketika inflsi meningkat bahwa akan berdampak pada pertumbuihan ekonomi yang meningkat juga.

\section{SARAN}

Berdasarkan hasil pembahasan dan analisis data diatas, ada beberapa saran yang diberikan untuk peneliti selanjutnya, anatraa lain sebagai berikut : 
1. Pemeerintah sebaiknya membuat atau mendorong para pengusaha untuk meningkatkan hasil produksinya. Memperbaiki sistem penggajian dan tingkat upah, melakukan pengawasan harga dan sekaligus menetapkan harga maksimal.

2. Pemerintah harap menciptakan lapangan pekerjaan baru, dengan memperhatikan usaha kecil, dan menengah karena pada sektor itulah orang yang banyak menganggur.

\section{DAFTAR PUSTAKA}

Adiwarman Karim,2014, Ekonomi Makro Islam, PT. Raja Grafindo, Jakarta.

Adrian Sutawijaya, Zulfahmi, Pengaruh faktor-faktor ekonomi terhadap inflasi di Indonesia, Jurnal Organisasi dan Manajemen, Volume 8, Nomor 2, September 2012, 85-10.

Alghofari, Farid, 2010. Analisis Tingkat Pengangguran di Indonesia Tahun 19802007.Undip.

Bick, Alexander, 2010, Threshold Effects of Inflation on Economic Growth in Developing Countries.

Budiono, 2009, Ekonomi Moneter. BPFE UGM, Yogyakarta.

Dharmayanti, Yenny. 2011. Analisis Pengaruh PDRB, Upah dan Inflasi terhadap Pengangguran Terbuka di Provinsi Jawa Tengah Tahun 1991-2009. Skripsi. Dipublikasikan.

Ditha, Rima Kurniasari. Analisis pengaruh investasi, inflasi, nilai tukar rupiah dan tingkat suku bunga terhadap pertumbuhan ekonomi di Indonesia, (Thesis, 2011).

Endri, 2008. Analisis Faktor-Faktor yang Mempengaruhi Inflasi di Indonesia. Dalam Jurnal Ekonomi Pembangunan Kajian Ekonomi Negara Berkembang, hlm: 61-70.

Engla Desnim Silvia, dkk, Analisis Pertumbuhan Ekonomi, Investasi, dan Inflasi di Indonesia , Jurnal Kajian Ekonomi,Vol. I, No. O2 Januari 2013,hlm. 224.

Fatmi Ratna Ningsih, Pengaruh Inflasi dan Pertumbuhan Ekonomi terhadap Pengangguran di Indonesia periode tahun 1988-2008 .

Isti Qomariyah, Dhiah Fitrayati. Pengaruh tingkat inflasi dan pertumbuhan ekonomi terhadap tingkat pengangguran di Jawa Timur, Jurnal Pendidikan Ekonomi (JUPE), vol 1, No 3 (2013).

Jonathan Sarwono, 2006, Metode Penelitian Kualitatif dan Kuantitatif, Graha Ilmu, Yogyakarta.

Mankiw N Gregory. 2003, Pengantar Ekonomi Makro. Edisi.3, Salemba Empat, Jakarta.

Maryam Sangadji, dkk, Analisis Pengaruh Inflasi dan Pertumbuhan Ekonomi terhadap Pengangguran di kota Ambon, Journal Ekonomi, 8, No. 1.

M Iqbal Hasan, 2005, Pokok-Pokok Materi Statistik 2 (Statistik Inferensif)), Bumi Aksara, Jakarta.

Muana Nanga, 2005, Makro Ekonomi:Teori, Masalah dan Kebijakan, Rajawali Pers, Jakarta.

Murni Asfia. Ekonomika Makro. (Bandung: Refika Aditama, 2006), hlm. 202

Pandangan Al-Maqrizi ini sangat jelas terlihat ketika ia menguraikan sebab-sebab berbagai bencana kelaparan yang menimpa Mesir sejak masa Mesir Kuno hingga masa pemerintahan Sultan Mamluk Bahri, Al-Ashraf Sha' ban (767-778 H/13631376 M). Lihat-ibid., hlm. 27-49.

Rahardja, Prathama dan Mandala Manurung. 2008, Teori Makro Suatu Pengantar FEUI, Jakarta. 
Rovia Nugrahani Pramesthi, Hendry Cahyono, Pengaruh pengangguran dan inflasi terhadap pertumbuhan ekonomi di Kabupaten Trenggalek, Jurnal Pendidikan Ekonomi (JUPE), vol 1, Mo 3,(2013).

Sakita Laksmi Dewi, Ida Nagus Putu Purbadharmaja. Pengaruh pad, pma dan inflasi terhadap pertumbuhan ekonomi Provinsi Bali, Jurnal Ekonomi,vol 2, No 11, November 2013, pp. 492-546.

Sujarweni, V. Wiratna, 2014, Metodologi Penelitian, Pustaka Baru Press, Yogyakarta. Sukirno, Sadono, 2000, Makroekonomi Modern. PT. Raja Grafindo Persada, Jakarta. 